\title{
MARIA FIRMINA DOS REIS, DECOLONIALIDADE E ESCRITA ABOLICIONISTA NA IMPRENSA MARANHENSE OITOCENTISTA
}

\section{Resumo}

No presente artigo, analiso o conto «A escrava», de Maria Firmina dos Reis, publicado na Revista Maranhense, . $^{\circ}$ 3, de 1887, por meio de uma leitura decolonial. O conto aborda o tema da escravização negra na perspectiva do sujeito escravizado, questionando, assim, o sistema-mundo moderno/colonial mesmo durante o pós-independência no Brasil. Utilizo a abordagem decolonial para refletir como Firmina põe em debate a hierarquização de raça e de gênero como elemento estruturante tanto da colonização quanto da escravização e, sobretudo, como ela, nas páginas da imprensa maranhense, lutou contra a lógica da colonialidade e suas implicações materiais, epistêmicas e simbólicas.

Palavras-chave: Maria Firmina dos Reis, decolonialidade, escravização negra.

\section{Abstract \\ Maria Firmina dos Reis, decoloniality and the abolitionist writing in the nineteenth century Maranhão Press}

This article analyzes the tale «A escrava» by Maria Firmina dos Reis, published in Revista Maranhense, no. 3, 1887, by means of a decolonial reading. The tale addresses the issue of black enslavement from the perspective of the enslaved subject, thus, questioning the modern/colonial world system even during the post-independence in Brazil. I use the decolonial approach to reflect on how Firmina puts into question the hierarchy of race and gender as a structuring element of both colonization and enslavement, and, above all, as she, in the pages of the Maranhão press, struggled against the logic of coloniality and its material, epistemic and symbolic implications.

Keywords: Maria Firmina dos Reis, decoloniality, black enslavement.

\section{Resumen}

Maria Firmina dos Reis, decolonialidad y la escrita abolicionista en la prensa de Maranhão en el siglo XIX

En el presente artículo, se analiza el cuento «A escrava», de Maria Firmina dos Reis, publicado en la Revista Maranhense, n. ${ }^{\circ}$ 3, de 1887, por medio de una lectura decolonial. El cuento aborda el tema de la esclavitud negra desde la perspectiva del sujeto esclavizado,

Centro de Documentação e de Pesquisa Maria Firmina dos Reis (CEMDOP/UFMA) da Universidade Federal do Maranhão, Avenida João Alberto de Sousa, s/n.

Bairro Bambu - Bacabal - MA 65700-000; Grupo de Estudos e de Pesquisa Literatura, História e Imprensa (GEPELHI/CNPq) da Universidade Federal de São Paulo, Unifesp, Guarulhos - SP CEP: 07252-312. Brasil.

Endereço postal: Rua Tiradentes, 130 - Ap. 43, Centro - Diadema, Cep. 09911-190 São Paulo.

Endereço eletrónico: cntolomei@yahoo.com.br

ORCID: https: / / orcid.org/0000-0001-7017-0943 
cuestionando así el sistema-mundo moderno/colonial mismo en la época de la post-independencia en Brasil. Utilizo el enfoque decolonial para reflexionar cómo Firmina pone en discusión la jerarquización de raza y género como elemento estructurante tanto de la colonización como de la esclavización y, sobre todo, cómo ella, en las páginas de la prensa de Maranhão, luchó contra la lógica de la colonialidad y sus implicaciones materiales, epistémicas y simbólicas.

Palabras clave: Maria Firmina dos Reis, decolonialidad, esclavización negra.

\section{Introdução}

A história do Brasil oitocentista, apesar do marco da independência em 1822, não difere muito dos séculos anteriores em relação às estruturas socioeconômicas da sociedade brasileira colonial. Num ambiente paradoxal, o país procurava modernizar-se, acompanhando as tendências da Revolução Americana (1776) e da Revolução Francesa (1789); mas, por outro lado, mantinha-se conservador em relação às velhas práticas coloniais, uma vez que o governo continuava nas mãos da Família Real Portuguesa, na figura do príncipe da dinastia dos Bragança, que se tornaria imperador do Brasil, D. Pedro I. Isto é, o movimento de libertação dispensou a participação popular, mantendo os interesses das elites dominantes que se agruparam em torno do príncipe herdeiro (Bosi 1992). Por conseguinte, a nova nação manteve as estruturas dos tempos de colônia praticamente durante todo o século XIX, nas quais a elite branca conservadora permanecia no poder e os indígenas, negros ${ }^{1}$ e mestiços continuavam excluídos e explorados. De acordo com a historiadora Emília Viotti da Costa, «conquistar a emancipação definitiva e real da nação, ampliar o significado dos princípios constitucionais foram relegados aos pósteros» $(2010,62)$. Desse modo, a colonialidade nas relações econômicas e sociais estava embasada nas diversas situações de dominação e opressão definidas pelo estabelecimento de fronteiras dicotômicas e hierárquicas como gênero, raça/etnia, classe social e localização geográfica.

A prática colonial do patriarcado controlou todo o sistema de poder e representação, enraizando no Brasil uma ideologia de hierarquização de gênero e de raça, a qual naturalizou as relações desiguais de força e poder. Assim, de maneira geral, as mulheres foram duplamente colonizadas, já que foram submetidas à dominação colonial portuguesa e à dominação do patriarcado. No caso específico das mulheres negras e indígenas, além dessa dupla colonização, foram tratadas como

\footnotetext{
Para o escritor Cuti (2010, 1), o termo negro faz referência à «pele escura, cabelo crespo, nariz largo e lábios carnudos e história social. Variações nesses itens são infinitas». Em contraposição, ele explica que «Afro» não necessariamente incorpora tal fenótipo, sobre o qual incide a insânia branca do racismo. Branca porque é dos brancos. Um «afro» pode ser branco. Há milhões deles. No «afro», o fenótipo negro se dilui». Portanto, a nossa opção pelo uso do termo negro/negra não somente como adjetivação da literatura ou de autoria, mas como nome, substantivo.
} 
objeto de curiosidade e de prazer masculino, sendo violadas de diferentes formas, sofrendo na violência a desigualdade de gênero e de raça no Brasil.

Mesmo nessa condição de subalternidade, as mulheres passaram a ganhar e/ ou conquistar os espaços até então destinados aos homens, como o jornalismo, e, devido a isso, a produção jornalística foi se intensificando no século XIX no país. Elas escreviam em jornais destinados somente para mulheres ou atuavam junto aos periódicos voltados ao público geral, publicando editoriais, ensaios, informes, charadas, músicas, poemas, crônicas, contos, novelas, romances e críticas em torno de diferentes assuntos: desde a maternidade, a defesa da família e do lar, da moda europeia e etiqueta, até ao que podemos chamar de um movimento protofeminista na luta pela libertação dos sujeitos escravizados, pelo direito à educação, à profissão e ao voto.

Dessa forma, o objetivo neste artigo é refletir sobre os efeitos da lógica colonial no Brasil, apesar da independência, nas relações econômicas, sociais e culturais durante o século XIX. Para isso, opto pela abordagem decolonial, uma vez que ela reconhece diretamente a história da América Latina, em específico, o contexto hispânico, todavia, neste estudo, transferi essa abordagem à realidade brasileira como forma de refletir a lógica da colonialidade e suas implicações materiais, epistêmicas e simbólicas da colonização portuguesa (Castro-Gómez e Grosfoguel 2007; Grosfoguel 2009; Bernardino-Costa e Grosfoguel 2016; Bernardino-Costa, Maldonado-Torres e Grosfoguel 2018; Maldonado-Torres 2018). Ademais, interessa-me, de forma mais pontual, refletir a hierarquização de raça e de gênero (Lugones 2008,2010 ) como elemento estruturante do sistema-mundo moderno/colonial ${ }^{2}$ (Mignolo 2003) vigente no Brasil mesmo no pós-independência.

Assim, analiso o conto «A escrava», da autora negra Maria Firmina dos Reis (1822-1917), publicado no número 3 do periódico do Maranhão intitulado A Revista Maranhense, de 1887, observando se de um lado a imprensa oitocentista brasileira enfatizava as relações coloniais de poder por meio das categorias de gênero, raça e classe; por outro lado, se houve um movimento de resistência a favor do desligamento das epistemologias eurocêntricas e coloniais, no qual Firmina fazia parte. Por conseguinte, apresento uma leitura do conto a partir do conceito decolonial, com o intuito de compreender a crítica escravagista realizada pela autora e o contexto de colonialidade em que se encontrava o Brasil no pós-independência.

A teoria do sistema-mundo é uma perspectiva macrossociológica que procura explicar a dinâmica da economia-mundo capitalista como um «sistema social total». De acordo com Wallerstein, é um «sistema que tem uma dinâmica própria que produz e reproduz relações entre processos e estruturas» $(1979,489)$. Uma das críticas que Walter Mignolo (2003) faz à teoria do sistema-mundo de Wallerstein é que esta deixou de considerar que a modernidade nasce junto com a colonialidade, constituindo um único processo. Assim, para os pensadores decoloniais, a colonialidade é o lado obscuro da modernidade e Mignolo propõe, então, a noção de sistema-mundo moderno/colonial para enfatizar essa concomitância entre colonialidade e modernidade e mostrar que ambas devem ser pensadas a partir de uma perspectiva de sistema-mundo. 


\section{Maria Firmina dos Reis: uma voz feminina negra contra a lógica da colo- nialidade}

Quando Maria Firmina dos Reis publicou seu primeiro romance, Úrsula, em 1859, e passou a escrever em diversos jornais maranhenses, o Brasil não era mais uma colônia de Portugal. Contudo, as elites brasileiras que tomaram o poder em 1822 continuaram a tradição colonial, subordinando o Estado à Igreja e mantendo o catolicismo como religião oficial, o patriarcado e o regime da escravidão por todo o período monárquico e imperial. Conforme Zilá Bernd (1988), o Brasil foi o último país da América a dar fim ao ultrapassado sistema escravocrata a fim de beneficiar a classe dominante enraizada na propícia condição colonial. Além disso, o Brasil continuou com a configuração básica em sua economia, apresentando um cenário de vinculação entre o sistema-mundo moderno/colonial e a escravização dos sujeitos negros.

Bosi $(1994,92)$ considera que esse período ainda estava sustentado pelas «colunas do poder agrário: o latifúndio, o escravismo, a economia de exportação» e esse cenário socioeconômico atingiu a inteligência brasileira e por consequência a produção literária.

a sociedade brasileira contou, para a formação da sua inteligência, com os filhos de famílias abastadas do campo, que iam receber instrução jurídica [...] em São Paulo, Recife e Rio (Macedo, Alencar, Álvares de Azevedo, Fagundes Varela, Bernardo Guimarães, Franklin Távora, Pedro Luís), ou com filhos de comerciantes luso-brasileiros e de profissionais liberais, que definiam, grosso modo, a alta classe média do país (Pereira da Silva, Gonçalves Dias, Joaquim Norberto, Casimiro de Abreu, Castro Alves, Sílvio Romero). Raros os casos de extração humilde na fase romântica, como Teixeira e Sousa e Manuel Antônio de Almeida, o primeiro narrado de folhetim, o segundo picaresco; ou do trovador semipopular Laurindo Rabelo (Bosi 1994, 92).

Nos raros casos de «extração humilde», Bosi, como quase toda historiografia literária brasileira, não cita a primeira escritora de romance de cunho antiescravista do país, Maria Firmina dos Reis, que desenvolveu uma significativa obra poética e em prosa na imprensa do Maranhão na segunda metade do século XIX.

A ideia de abolição e rompimento total com a estrutura colonial dos séculos anteriores sempre esteve atrelada ao movimento intelectual e artístico do Sul do país. As novas elites urbanas, a partir da década de 1870, não se sentiam representadas pelas estruturas políticas do Império, e republicanos e abolicionistas passaram a adotar um estilo novo de política: os debates ocorriam nas praças, nas páginas da literatura e da imprensa, logo, nomes como Castro Alves e Luiz Gama se destacavam, especialmente, em São Paulo, sendo uma força nos movimentos abolicionistas. A respeito desse assunto, Antonio Candido afirma que «o tema do negro avultou nessa fase e suscitou, da parte dos escritores, uma tomada de posição na luta contra a escravidão, que cresceu depois da Guerra do Paraguai» $(2012,68)$. 
Todavia, antes disso, no Nordeste brasileiro, surgia, na imprensa maranhense, a escritora negra Maria Firmina dos Reis. Marginalizada pela historiografia literária brasileira, ela rompeu com o princípio constitutivo do racismo e do sexismo nas relações sociais do período para denunciar o sistema-mundo moderno/colonial/ patriarcal $^{3}$ e a escravização do sujeito negro.

Firmina é um fenômeno, pois nascida afrodescendente fora do casamento em 11 de março de 1822, em São Luís do Maranhão, e vivendo num contexto de extrema segregação racial e social, ela é batizada somente em 21 de dezembro de 1825, constando na certidão sua condição de «filha natural» de Leonor Felippa dos Reis (mulata forra) e estando ausente do documento o nome de seu pai (Vaz e Adler 2015). Ainda com cinco anos, ficou órfã e teve que se mudar para a casa da tia materna na vila de Guimarães, também no Maranhão, e foi lá que se formou professora e passou a produzir literatura. Mesmo sendo destaque na educação, na literatura e no jornalismo maranhense, faleceu em 11 de novembro de 1917, com 92 anos, cega, pobre e sem a valorização merecida (Mendes 2016).

A autora sempre esteve à frente de seu tempo e conseguiu ultrapassar a barreira do racismo e do sexismo; além do já citado romance Úrsula, contribuiu assiduamente para a imprensa local, publicando charadas/enigmas, poesia, o conto «A escrava» (1887) e o romance indianista Gupeva, publicado inicialmente em forma de folhetim no jornal Jardim das Maranhenses (1861), e republicado em 1863 e 1865, respectivamente, nos jornais Porto Livre e Eco da Juventude.

Colaborou com os jornais maranhenses O Progresso (1847), A Imprensa (18601861), O Jardim das Maranhenses (1861-1862), Publicador Maranhense (1861), Porto Livre (1863), Eco da Juventude (1865), A Verdadeira Marmota (1867), Semanário Maranhense (1867-1868), O Domingo (1872), O País (1881-1885), A Revista Maranhense (1887), Diário do Maranhão (1889), Pacotilha (1885-1900), Federalista (1903). Intitulando-se «Uma maranhense» ou assinando com a sigla MFR, ela entrou no universo jornalístico do Maranhão, dominado quase que exclusivamente por homens brancos, burlando, além do preconceito de gênero, o preconceito de raça daquela época.

Embora com uma produção considerável, a autora ficou muito tempo no ostracismo, voltando ao interesse público em 1975, quando José Nascimento de Morais Filho (1975) publicou Maria Firmina: fragmentos de uma vida, obra que reúne escritos da autora e depoimentos de ex-alunos. No mesmo ano, ocorre a reedição de Úrsula em edição fac-similar por Horácio de Almeida. Daí por diante a obra firminiana foi ganhando espaço e passando a ser reeditada constantemente e ganhando diversos estudos analíticos em diferentes áreas do conhecimento (Zin 2016).

Ramón Grosfoguel (2011) nomeia como «sistema-mundo capitalista/patriarcal/ocidental-cêntrico/ cristão-cêntrico/moderno/ colonial» a civilização formada a partir da expansão colonial europeia de 1492. Essa expressão, neste artigo, surge completa ou reduzida de acordo com os elementos analisados na obra de Maria Firmina dos Reis. 


\section{A decolonialidade e a escrita feminina negra}

Para refletir a respeito da continuidade da lógica colonial na América Latina, uma rede de pesquisadores latino-americanos, a partir da década de 1990, lançou novas bases e categorias interpretativas da realidade mediante experiências locais, daí o surgimento do projeto decolonial, que consiste numa prática de oposição e resistência ao sistema-mundo moderno/colonial (Castro-Gómez e Grosfoguel 2007).

A concepção decolonial surge da necessidade de criar uma espécie de movimento de resistência política, teórica e epistêmica perante a permanência da colonialidade de gênero, de raça, de localização geográfica e de pensamento com base no sistema hierárquico e na lógica global de desumanização capaz de existir até mesmo na ausência de colônias formais na América Latina (Maldonado-Torres 2018).

Embora seja reconhecida a contribuição da crítica pós-colonial, ela sempre se concentrou em uma única perspectiva epistêmica, aquela baseada no pensamento pós-estruturalista de Foucault, Lacan e Derrida, e não levava em consideração outras epistemes. Logo, os críticos pós-coloniais, tomando como base a colonização francesa e britânica da Ásia, África e Oceania, que teve seu auge no século XIX até a primeira metade do XX, teriam ignorado os trezentos anos anteriores de colonização ibérica nas Américas.

No contexto da América Latina, a lógica da inferioridade em relação ao europeu naturalizou relações coloniais de divisão sexual e racial de trabalho no âmbito do capitalismo mundial. Em vista disso, o discurso colonial resultou em diferentes projetos políticos feministas para a conquista de direitos nas relações pessoais, trabalhistas, culturais e intelectuais, tais como direito à educação básica e superior; direito ao trabalho, no caso, mulheres atuando nos jornais; direitos civis garantidos, mesmo casadas, etc.

Sobre a colonização de gênero, Lugones (2010) ressalta que a colonização das Américas e do Caribe foi marcada pela hierarquia dicotômica entre o humano e o não-humano como fator preponderante do sistema-mundo moderno e colonial eurocêntrico. Em consequência dessa hierarquização, passou-se a distinguir homens e mulheres dentro desse sistema: o homem branco, detentor da razão e da inteligência; a mulher branca, reprodutora da dominação colonial e da mentalidade dominante; e os não-humanos, negros e indígenas. Lugones afirma ainda que negras e indígenas não estão representadas nem na categoria universal de «mulher», nem nas categorias índio e negro, logo não existe «mulher negra» e nem «mulher índia», sendo necessária outra classificação que seja especificamente representativa. Portanto, a crítica que ela faz às teorias feministas generalizantes é que, segundo ela, são excludentes de mulheres com especificidades relativas à raça e classe, e, para superar essa dominação colonial, é preciso construir um feminismo decolonial capaz de elaborar categorias representativas dos não-ditos da modernidade e colonialidade no tocante ao gênero. 
Dialogando com Lugones, Grosfoguel (2018) afirma que a luta política das mulheres negras significa colocar em primeiro plano o debate em torno de gênero e de raça, refutando a lógica colonial capitalista da relação hierárquica, na qual o racismo é um princípio organizador de todas as configurações sociais e relações de dominação da modernidade.

A colonialidade não admitiu a existência da diferença, fundando a divisão internacional étnica-racial e sexual do trabalho, além de propagar a lógica patriarcal embasada nas práticas sexistas e misóginas, resultando violências de diversos formatos contra a mulher no regime colonial e após ele. Em vista disso, o feminismo, numa perspectiva decolonial, destaca-se ao propor uma revisão crítica das estruturas de dominação do conhecimento e de opressão de gênero e de raça na América Latina. Dessa forma, os lugares enunciativos passam a ser espaços onde os conhecimentos são formulados a partir da cosmovisão e da experiência dos sujeitos subalternizados (Bernardino-Costa e Grosfoguel 2016), no caso, como Maria Firmina dos Reis, que rompeu com o sistema-mundo moderno/colonial-capitalista/patriarcal (Grosfoguel 2018), tornando-se em si a própria ruptura para, consequentemente, denunciar a escravidão do sujeito negro em sua obra literária, sobretudo, no conto «A escrava».

Sobre o racismo como fenômeno produzido pelo mundo moderno depois da expansão europeia, que se constituiu na separação dos «seres superiores» em relação aos «seres inferiores», Grosfoguel $(2018,102)$ acrescenta que ele «é um princípio constitutivo que organiza, a partir de dentro, todas as relações de dominação da modernidade, desde a divisão internacional do trabalho até as categorias epistêmicas, sexuais, de gênero, religiosas, pedagógicas, médicas» $(2018,102)$.

Dessa forma, conseguindo romper com o racismo institucionalizado pelo sistema-mundo moderno/colonial, Firmina exerce uma prática de escrita feminina sociopolítica, desconstruindo o discurso dominante e redirecionando o lugar de enunciação ao documentar, pelo viés literário na imprensa maranhense, as violências da representação e da opressão, acima de tudo, sobre os sujeitos negros escravizados no Brasil.

\section{Conto «A escrava»: uma leitura decolonial}

Como notou Eduardo de Assis Duarte a propósito da autora, «ao estabelecer uma diferença discursiva que contrasta em profundidade com o abolicionismo hegemônico na literatura brasileira de seu tempo, a autora constrói para si mesma um outro lugar: o da literatura afro-brasileira» $(2017,277)$.

No conto «A escrava», Firmina revisita suas experiências como mulher negra do interior de uma das mais conservadoras províncias do Brasil na época para rejeitar a relação hierárquica de raça e de gênero. Para isso, a história é contada pela perspectiva do sujeito negro escravizado, recriando e subvertendo fronteiras. 
Convém observar que no conto há alternância de narradoras: ambas correferenciais, mas distintas na posição em que estão situadas na narrativa. A história é conduzida por uma narradora homodiegética que, além de personagem da história, é testemunha do conflito trágico da narrativa. Não lhe é atribuído nome, aludindo às escritoras que tiveram seus nomes apagados na historiografia literária nacional. Essa narradora homodiegética representa a mulher branca abolicionista, lutando na causa justa contra a escravidão. A outra narradora, autodiegética, narra a sua própria história e seu nome é Joana, senhora negra escravizada. A identificação de Joana é um ato de resistência de Firmina ao dar visibilidade para o sujeito que foi negado por sua raça e gênero no decorrer da colonização. Ademais, o depoimento do sujeito negro escravizado na narrativa é importante para refletir como a dimensão estruturante do sistema-mundo moderno/colonial, embasada na hierarquização de raça e de gênero, colocou o preconceito como princípio organizador estruturante nas relações sociais de dominação da modernidade (Grosfoguel 2018).

A narradora homodiegética, apesar de participar da sociedade mais abastada do Maranhão, sente-se deslocada diante da frivolidade e banalidade da conversa numa reunião social que abre a narrativa. Segundo ela, as pessoas conversavam sobre «diversos assuntos mais ou menos interessantes» (Reis 2018, 164) ${ }^{4}$ e, sem hesitar, ela modifica o teor da conversa, propondo tema muito relevante: «o elemento servil» (Reis 2018, 164). A discussão em torno do trabalho escravo resultou em opiniões diferentes entre aqueles que aceitavam a situação e outros, como a nossa narradora, que rejeitavam a condição sub-humana do sujeito escravizado no Brasil.

- Admira-me, - disse uma senhora de sentimentos sinceramente abolicionistas; - faz-me até pasmar como se possa sentir, e expressar sentimentos escravocratas, no presente século, no século dezenove! A moral religiosa e a moral cívica aí se erguem, e falam bem alto esmagando a hidra que envenena a família no mais sagrado santuário seu, e desmoraliza, e avilta a nação inteira! (Reis 2018, 164).

No trecho, notamos a presença da moral religiosa cristã na sociedade brasileira, instituída pelo sistema-mundo moderno/colonial/cristão-cêntrico (Grosfoguel 2009), determinando o ideal de conduta social com base nos costumes cristãos, os quais teoricamente deveriam repudiar a escravatura, porém, como é sabido, a Igreja Católica apoiou a mão de obra escrava com fins lucrativos e interesses políticos. Ademais, essa religiosidade que se compadece e, ao mesmo tempo, mascara o sofrimento do sujeito escravizado, favorece a interpretação de que o sistema da escravidão na América Latina foi benevolente e paternalista (Costa 2010).

4 O conto «A escrava» foi reeditado em vários momentos, mas para este trabalho optou-se pela edição da Câmara dos Deputados que marca oficialmente a recepção/distribuição da obra de Maria Firmina dos Reis, além de incluí-la na série clássicos da literatura brasileira. 
A autora questiona o mundo ideal pregado pela religião cristã, pois foi pela Providência que a Igreja Católica colaborou, de forma fundamental, para o funcionamento do sistema colonial mercantil, pré-capitalista e pré-tecnológico. A respeito disso, Costa $(2010,356)$ ressalta que «a Igreja bem cedo estabeleceu um compromisso entre escravidão e cristianismo, encontrando na tradição ocidental os argumentos para justificar a escravidão de negros» $(2010,356)$.

No mesmo trecho do conto, há a presença da figura mitológica «hidra», um monstro com corpo de dragão e várias cabeças de serpente, na contramão do cristianismo e simbolizando a religião politeísta da cultura greco-romana. Essa figura, no contexto do conto, representa, metaforicamente, o discurso escravocrata da violência que crescia cada vez mais na sociedade brasileira, já que para cada cabeça cortada da hidra, cresciam duas ou mais, ou seja, para cada abolicionista que surgia, dois ou mais escravocratas surgiam também. Firmina aponta para o que parece um ciclo sem fim, como se a escravidão gerasse novos adeptos a todo instante, daí a importância do conto «A escrava» para promover o debate e apontar para as mazelas sociais e culturais que a escravidão gerava mesmo um ano antes da abolição. Conforme Grosfoguel, a «modernidade/colonialidade é um projeto civilizatório, que se produz no calor da violência e difunde com a violência em uma escala planetária que gerou a expansão colonial europeia para produzir vida» (2018, 45).

Ainda no debate entre as personagens acerca do «trabalho servil», a autora denuncia no conto a escravidão como degradação social, desonra pública e atraso, ou seja, critica a herança colonial portuguesa e seus efeitos racistas. Ademais, recorre à ideia de mestiçagem como argumento para o fim da escravidão.

Por qualquer modo que encaremos a escravidão, ela é, e será sempre um grande mal. Dela a decadência do comércio; porque o comércio e a lavoura caminham de mãos dadas, e o escravo não pode fazer florescer a lavoura; porque o seu trabalho é forçado. Ele não tem futuro; o seu trabalho não é indenizado; ainda dela nos vem o opróbrio, a vergonha; porque de fronte altiva e desassombrada não podemos encarar as nações livres; por isso que o estigma da escravidão, pelo cruzamento das raças, estampa-se na fronte de todos nós. Embalde procurará um dentre nós, convencer ao estrangeiro que em suas veias não gira uma só gota de sangue escravo (Reis 2018, 164-165).

No recorrente discurso da mestiçagem, entendido no Brasil como a notável plasticidade racial, resultando no legado de afabilidade inter-racial nos brasileiros, defendido por Gilberto Freire (1933), em Casa Grande e Senzala, criou-se uma noção de democracia racial à brasileira, em que os brasileiros deveriam aceitar-se para que não se lamentassem do complexo de inferioridade por não terem sido colonizados pelos ingleses ou pelos batavos. Firmina antecipa a ideia de democracia racial freiriana no século XIX para defender o fim da escravidão, argumentando a favor da valorização da miscigenação. Todavia, vale ressaltar que a escritora usa a 
tese da mestiçagem como estratégia para comover e atrair o público leitor da Revista Maranhense, uma vez que a elite branca brasileira da época, por interesses próprios, levava aos quatros cantos do país o ideal inter-racial, daí o instrumento de convencimento da autora, pois acreditamos que ela tinha consciência de que a lógica colonial da miscigenação no Brasil era para obscurecer formas de opressão racial, resultando no «mito racial».

A narradora homodiegética, após notar que os escravocratas estavam ganhando dos abolicionistas no debate, resolve contar uma história sobre uma senhora negra escravizada, de nome Joana, para provar a crueldade da escravidão.

A narradora homodiegética, imersa num ideal romântico de paisagem, exaltando a harmonia entre a natureza e ela, situada numa espécie de limbo, onde não havia problemas de nenhuma espécie, é interrompida por uma senhora negra escravizada fugindo de seu carrasco. Nesse momento, a escritora interrompe, de forma abrupta, a descrição paradisíaca da narradora, quando traz para a narrativa o conflito dramático que dará base para a continuidade da narrativa, mas, sobretudo, para a proposta de crítica social.

- Era uma tarde de agosto, bela como um ideal de mulher, poética como um suspiro de virgem, melancólica e suave como sons longínquos de um alaúde misterioso.

Eu cismava, embevecida na beleza natural das alterosas palmeiras que se curvaram gemebundas, ao sopro do vento, que gemia na costa.

E o sol, dardejando seus raios multicores, pendia para o ocaso em rápida carreira. [...]

De repente uns gritos lastimosos, uns soluços angustiados feriram-me os ouvidos, e uma mulher correndo, e em completo desalinho, passou por diante de mim, e como uma sombra desapareceu (Reis 2018, 165).

Num trecho de prosa-poética Firmina coloca frente a frente o ideal romântico da elite branca com a realidade violenta da mulher negra escravizada. Joana, cafuza, filha de mãe africana e pai indígena, foge do feitor Antônio, subordinado do senhor Tavares. O impacto dos «gritos lamentosos» de Joana rompe com o estado inicial da narrativa em flashback para determinar o ritmo do testemunho da narradora homodiegética, que, confortável na condição de mulher branca e de elite, passa a narrar a história de Joana, que é muito diferente da experiência de vivência da narradora, ocorrendo um choque de percepção.

Mesmo cafuza, ou seja, de cor mais clara, Joana era perseguida por um homem pardo, também de tom de pele mais claro, mas em situações díspares: enquanto Joana sofria a perseguição e a violência da escravidão; Antônio, sujeito subalternizado que acreditava ocupar um lugar superior, era o braço opressor do senhor escravocrata.

Era ele de cor parda, de estatura elevada, largas espáduas, cabelos negros, e anelados. Fisionomia sinistra era a desse homem, que brandia, brutalmente, na mão direita um azorrague repugnante; e da esquerda deixava pender uma delgada corda de linho. 
- Inferno! Maldição! - bradara ele com voz rouca. - Onde estará ela? - e perscrutava com a vista por entre os arvoredos desiguais que desfilavam à margem da estrada.

- Tu me pagarás - resmungava ele (Reis 2018, 166).

Mais uma vez convém observar que o feitor era "pardo», mistura entre negro e branco ou indígena e branco, o que o deixaria numa situação mais confortável, já que naquele período quanto mais clara a cor da pele, mais mobilidade social era permitida, infelizmente, não para Joana. Sobre isso, Grosfoguel (2009) ressalta que o sistema-mundo/colonial teve sucesso, pois levou os sujeitos socialmente situados no lado oprimido da diferença colonial a pensarem epistemicamente como aqueles que se encontravam em posições dominantes.

Aceitando a conveniente lógica colonial, a personagem Antonio, acreditando estar inserido nos paradigmas eurocêntricos hegemônicos, trata os sujeitos escravizados com violência, usando a estratégia de desumanização para que o escravizado não ultrapasse seu lugar social:

- Maldita negra! Esbaforido, consumido, a meter-me por estes caminhos, pelos matos em procura da preguiçosa... Ora! Hei de encontrar-te; mas, deixa estar, eu te juro, será esta a derradeira vez que me incomodas. No tronco... no tronco: e de lá foge! (Reis 2018, 166).

$\mathrm{Na}$ fala do feitor, verifica-se como ele se apropria do discurso do colonizador branco, embasada na teoria determinista-naturalista para justificar a hierarquização das raças, como meio de inferiorizar a negra Joana por sua «preguiça». Segundo Kabengele Munanga, os naturalistas e os iluministas reforçaram o estigma do negro descrito por sua «sexualidade, nudez, feiura, preguiça e indolência» $(2004,30)$. Assim, Maria Firmina dos Reis, no excerto, aponta como a leitura racial, legitimada pela ciência, consolidou a visão pejorativa do negro na sociedade brasileira, justificando a colonização e a escravidão.

Podemos considerar Antônio um «privilegiado» que, por ser pardo e livre, era agente da violência durante a escravatura e não passivo, o recebedor da violência como Joana. Ela que poderia ser livre, especificamente, por ter a pele mais clara, foi cativa desde os sete anos de idade. O pai dela foi enganado pelo senhor Tavares, que recebeu a quantia para a compra da alforria de Joana, mas entregou uma folha sem valor oficial. Joana ainda recebeu instrução e aprendeu a ler com um «mulato» livre, quando ainda seu pai estava vivo, mas no falecimento dele, o senhor Tavares escravizou a menina Joana junto com a mãe, e esta não suportou e morreu.

A narradora homodiegética além de salvar Joana da perseguição, também acode Gabriel, filho de Joana, que estava desesperado atrás da mãe.

Era quase uma ofensa ao pudor fixar a vista sobre aquele infeliz, cujo corpo seminu mostrava-se coberto de recentes cicatrizes; entretanto sua fisionomia era franca, e agradável. O rosto negro, e descarnado; suposto seu juvenil aspecto aljo- 
farado de copioso suor, seus membros alquebrados de cansaço, seus olhos rasgados, ora deferindo luz errante, e trêmula, agitada, e incerta traduzindo a excitação, e o terror, tinham um quê de altamente interessante (Reis 2018, 167-168).

Acolhendo a causa de resistência de ambos os sujeitos escravizados, a narradora homodiegética se comove com a situação degradante e assustadora de Joana e Gabriel, contudo, como informa, «apesar do medo que nos causa a presença dum calhambola, aproximei-me dele» (Reis 2018, 168). No relato da narradora, mesmo ela sendo abolicionista, há resquício de uma lógica colonial ao tratar Gabriel de «calhambola», negro fugido, e o medo diante da presença dele. Após esse primeiro contato de estranhamento entre a narradora e Gabriel, ela passa a ouvir o que ele tem a dizer.

- Ah! Minha senhora, - exclamou erguendo os olhos ao céu, - eu procuro minha mãe, que correu nesta direção, fugindo ao cruel feitor, que a perseguia. Eu também agora sou um fugido: porque há uma hora deixei o serviço para procurar minha pobre mãe, que além de doida está quase a morrer. Não sei se ele a encontrou; e o que será dela. Ah! Minha mãe! [...]

- Aquele homem é um tigre, minha senhora, é uma fera. Ouvia-o, sem o interromper, tanto interesse me inspirava o mísero escravo. [...]

- Escuta, - lhe tornei então, - tua mãe está salva, salvou-a o acaso; e o feitor está agora bem longe daqui (Reis 2018, 168).

A narradora, «membro da sociedade abolicionista da nossa província [Maranhão] e da do Rio de Janeiro» (Reis 2018, 171), acolheu em sua casa os negros fugidos e nesse momento, mais uma vez, Firmina utiliza o artifício religioso como uma «estratégia autoral de combate ao regime, sem agredir em demasia as convicções dos leitores brancos» (Duarte 2017, 215).

Entretanto, a enferma pouco e pouco recobrava as forças, a vida, e a razão.[...]

- Gabriel? Gabriel? - És tu?

- É noite. Eu morro... E o serviço? E o feitor?

- Estás em segurança, pobre mulher, disse-lhe, - tu e teu filho estão sob a minha proteção. Descansa, aqui ninguém lhes tocará com um dedo. [...]

Sorriu-se e murmurou.

- Inda há neste mundo quem se compadeça de um escravo?

- Há muita alma compassiva, - retorqui-lhe, - que se condói do sofrimento de seu irmão. [...]

-Quem é vossemecê, minha senhora, que tão boa é para mim, e para meu filho? Nunca encontrei em vida um branco que se compadecesse de mim; creio que Deus me perdoa os meus pecados, e que já começo a ver seus anjos (Reis 2018, 171). 
No Brasil, muito diferente da ortodoxia puritana dos colonizadores ingleses e até mesmo do catolicismo espanhol, consolidou-se uma religiosidade peculiar, pois o sujeito escravizado foi levado a aceitar a fé cristã como forma de salvar sua alma. Assim, como é possível notar no excerto anterior, a fala de Joana está impregnada de preceitos cristãos como pecado, perdão, anjos e Deus como símbolo de bênção mediante a ajuda da senhora branca. Em vista disso, a Igreja Católica pregava a teologia cristã de um Deus de conquistadores/colonizadores, justificando o sistema da escravidão; e um Deus de conquistados/colonizados, no qual os sujeitos escravizados aceitavam sua condição desumana de exploração, facilitando, por conseguinte, a manutenção e o fortalecimento dessa condição.

Joana, que estava à beira da morte, toma a narrativa para si, e na função de narradora autodiegética, conta a sua história de infortúnios num depoimento trágico em torno da venda de seus dois filhos de oito anos, os gêmeos Carlos e Urbano. Ao dar voz para a senhora negra escravizada, Maria Firmina dos Reis abre espaço para que finalmente os silenciados pela opressão e pela violência de raça e de gênero consigam denunciar o sistema-mundo/colonial.

À hora permitida ao descanso, concheguei a mim meus pobres filhos, extenuados de cansaço, que logo adormeceram. Ouvi ao longe rumor, como de homens que conversavam. Alonguei os ouvidos; as vozes se aproximavam. Em breve reconheci a voz do senhor. Senti palpitar desordenadamente meu coração; lembrei-me do traficante... corri para meus filhos, que dormiam, apertei-os ao coração. Então senti um zumbido nos ouvidos, fugiu-me a luz dos olhos e creio que perdi os sentidos.

Não sei quanto tempo durou este estado de torpor; acordei aos gritos de meus pobres filhos, que me arrastavam pela saia, chamando-me: mamãe! Mamãe! (Reis 2018, 173).

Após seu depoimento, Joana falece, derrotada pelo sistema-mundo/colonial/ escravocrata que submetia os sujeitos negros escravizados à extrema violência, como foi possível observar no trecho a respeito da venda de crianças como mão de obra, rompendo laços entre os familiares de forma cruel e tudo com fins lucrativos em prol do capital. A cena, contada por Joana, «subverte os estereótipos do bom senhor e do escravo contente» (Duarte 2017, 219), e rompe com a visão paternalista da escravidão no Brasil. Na fala dramática da narradora autodiegética, a voz do oprimido ganha destaque tanto na imprensa maranhense um ano antes da abolição da escravatura, quanto na literatura brasileira que até então tinha a voz do escravizado camuflada ou silenciada.

Firmina cria Joana como protagonista do discurso do sujeito escravizado que revela o caráter desonesto e cruel do colonizador/senhor de escravo, no caso do conto, Tavares, mas também a bondade da senhora abolicionista, a narradora homodiegética.

A maldade de Tavares aparece por todo o conto, desde a fraude da carta de alforria da menina Joana, na venda dos gêmeos até à morte da senhora negra escra- 
vizada. Logo, Tavares, representando o discurso colonial/escravocrata, busca Gabriel na casa da senhora abolicionista e da cena notamos a relação de posse e de poder em relação ao submisso jovem negro escravizado.

Porém, minha senhora, este negro! - designava o pobre Gabriel, - com este negro a coisa muda de figura; minha querida senhora, este negro está fugido; espero, mo entregará, pois sou o seu legítimo senhor, e quero corrigi-lo (Reis 2018, 176).

Na fala de Tavares, verificamos como a lógica colonial de hierarquização de raça sobreviveu no pós-independência. Segundo Maldonado-Torres, a «independência, todavia, não necessariamente implica descolonização na medida em que há lógicas coloniais e representações que podem continuar existindo depois do clímax específico dos movimentos de libertação e da conquista de independência» (2018, 46-47). Em vista disso, o sujeito negro escravizado sofre com as colonialidade do ser, do saber e do poder durante e depois da colonização no Brasil.

E, diante desse cenário, Maria Firmina dos Reis sensibiliza o leitor para que passe a aceitar e promover os ideais abolicionistas, especialmente no final do conto, quando Gabriel é liberto pela senhora: «Gabriel ergue a fronte, Gabriel és livre» (Reis 2018, 177). Cena que simboliza o ideal libertário e o fim da lógica do sistema-mundo moderno/colonial, capitalista.

Logo, a decolonialidade em Firmina está na forma como ela se opõe e intervém, pelo viés literário, a lógica vertical da colonialidade, propondo uma relação horizontal na sociedade brasileira, sem hierarquização racial, de gênero e de classe que incidem, sobretudo, no corpo negro. Ademais, Firmina aponta no conto, por meio de tensões ideológicas, a necessidade de uma sociedade brasileira igualitária e justa na luta contra o patriarcado e o racismo e para isso, de forma pioneira, divulga seu projeto de resistência contra a escravidão, sendo mulher, negra e periférica no século XIX. Assim, ela assumiu uma postura abolicionista nos jornais com poemas de temática social, especialmente, o «Hino à liberdade dos escravos», expoente de sua luta contra a escravidão, colaborando para conscientizar os leitores maranhenses e construindo um projeto de resistência na inversão de papéis: na posição sempre positiva do colonizador branco passa a situar-se finalmente o negro escravizado.

\section{Referências bibliográficas}

Bernardino-Costa, Joaze, e Ramón Grosfoguel. 2016. «Decolonialidade e perspectiva negra». Revista Sociedade e Estado 31 (1): 15-24.DOI: https: / / doi.org/10.1590/S0102-69922016000 100002

Bernardino-Costa, Joaze, Nelson Maldonado-Torres, e Ramón Grosfoguel. 2018. «Introdução. Decolonialidade e pensamento afrodiaspórico». In Decolonialidade e pensamento afrodiaspórico, organizado por Joaze Bernardino-Costa, Nelson Maldonado-Torres e Ramón Grosfoguel, 8-43. Belo Horizonte: Autêntica. 
Bernd, Zilá. 1988. Introdução à literatura negra. São Paulo: Brasiliense.

Bosi, Alfredo. 1992. «A escravidão entre dois liberalismos». In Dialética da colonização, 194245. São Paulo: Companhia das Letras.

Bosi, Alfredo. 1994. História concisa da literatura brasileira. São Paulo: Cultrix.

Candido, Antonio. 2012. O Romantismo no Brasil. São Paulo: Humanitas.

Castro-Gómez, Santiago, e Ramón Grasfoguel, eds. 2007. El giro decolonial: reflexiones para una diversidad epistémica más allá del capitalismo global. Bogotá: Siglo del Hombre Editores.

Costa, Emília Viotti da. 2010. Da Monarquia à República. São Paulo: EDUNESP.

Cuti. 2010. "Quem tem medo da palavra negro». Revista Matriz: uma revista de arte negra. 1-13. Porto Alegre. Disponível em http: / / www.sedes.org.br/Departamentos/Psicanalise/pdf/quemtemmedodapalavranegro_cuti.pdf

Duarte, Eduardo de Assis. 2017. «Úrsula e a desconstrução da razão negra ocidental» (Posfácio). In Úrsula, por Maria Firmina dos Reis, 209-236. 6. ${ }^{a}$ ed. Belo Horizonte: Editora PUC Minas.

Freire, Gilberto. 1933. Casa-Grande E Senzala: formação da familia brasileira sob o regime da economia. São Paulo: Global.

Grosfoguel, Ramón. 2009. «Para descolonizar os estudos de economia política e os estudos pós-coloniais: transmodernidade, pensamento de fronteira e colonialidade global». Revista Crítica de Ciências Sociais, 80: 115-147. DOI: https: / / doi.org/10.4000/rccs.697

Grosfoguel, Ramón. 2011. «Decolonizing Post-Colonial Studies and Paradigms of PoliticalEconomy: Transmodernity, Decolonial Thinking and Global Coloniality». Transmodernity: Journal of Peripheral Cultural Production of the Luso-Hispanic World 1 (1): 1-37. Disponível em https:/ / escholarship.org/uc/item/21k6t3fq

Grosfoguel, Ramón. 2018. «Para uma visão decolonial da crise civilizatória e dos paradigmas da esquerda ocidentalizada». In Decolonialidade e pensamento afrodiaspórico, organizado por Joaze Bernardino-Costa, Nelson Maldonado-Torres e Ramón Grosfoguel, 94-137. Belo Horizonte: Autêntica.

Lugones, María. 2008. «The Coloniality of Gender». In Worlds \& Knowledges Otherwise 2 (Spring): 1-17. Disponível em https:/ / globalstudies.trinity.duke.edu/sites/globalstudies.trinity.duke.edu/files/file-attachments/v2d2_Lugones.pdf

Lugones, María. 2010. «Toward a Decolonial Feminism». In Hypatia 25 (4): 742-759. DOI: https: / / doi.org/10.1111/j.1527-2001.2010.01137.x

Maldonado-Torres, Nelson. 2018. «Analítica da colonialidade e da decolonialidade: algumas dimensões básicas». In Decolonialidade e pensamento afrodiaspórico, organizado por Joaze Bernardino-Costa, Nelson Maldonado-Torres e Ramón Grosfoguel, 44-93. Belo Horizonte: Autêntica.

Mendes, Algemira de Macêdo. 2016. A escrita de Maria Firmina dos Reis na literatura afrodescendente brasileira: revisitando o cânone. São Paulo, Lisboa: Chiado.

Mignolo, Walter. 2003. Histórias locais/projetos globais. Colonialidade, saberes subalternos e pensamento liminar. Belo Horizonte: Editora UFMG.

Morais Filho, José Nascimento. 1975. Maria Firmina: fragmentos de uma vida. São Luís: Edição do autor.

Munanga, Kabengele. 2004. «Uma abordagem conceitual das noções de raça, racismo, identidade e etnia». In Cadernos PENESB, organizado por André Augusto Brandão, 15-34. Niterói: EDUFF.

Reis, Maria Firmina dos. 2018. «A Escrava». In Úrsula e outras obras, por Maria Firmina dos Reis, 163-177. Brasília: Câmara dos Deputados, Edições Câmara.

Vaz, Leopoldo Gil Dulcio, e Dilercy Aragão Adler, orgs. 2015. Sobre Maria Firmina dos Reis. São Luís: ALL. 
Wallerstein, Immanuel. 1979. El Moderno Sistema Mundial. La agricultura capitalista y los orígenes de la economía-mundo europea en el siglo XVI. México: Siglo Veintiuno Editores.

Zin, Rafael Balseiro. 2016. Maria Firmina dos Reis: a trajetória intelectual de uma escritora afrodescendente no Brasil Oitocentista. Dissertação de Mestrado, Pontifícia Universidade Católica de São Paulo.

Cristiane Navarrete Tolomei. Doutora em Letras pela Universidade de São Paulo (USP). Atua na Universidade Federal do Maranhão como professora adjunta de Literatura e é docente do Programa de Pós-Graduação em Cultura e Sociedade (PGCult/ UFMA). É líder do Grupo de Estudos e de Pesquisa Literatura, História e Imprensa (GEPELHI/CNPq) e diretora do Centro de Documentação e de Pesquisa Maria Firmina dos Reis (CEMDOP/UFMA).

Endereço eletrónico: cntolomei@yahoo.com.br

Artigo recebido a 21 de fevereiro de 2019 e aceite para publicação em 4 de abril de 2019. 